Mothering from the Field 



\title{
Mothering from the Field
}

\section{The Impact of Motherhood on Site-Based Research}

\author{
EDITED BY BAHIYYAH MIALLAH MUHAMMAD \\ AND MÉLANIE-ANGELA NEUILLY
}

\section{in}

Rutgers University Press

New Brunswick, Camden, and Newark, New Jersey, and London 
Library of Congress Cataloging-in-Publication Data

Names: Muhammad, Bahiyyah Miallah, 1980- editor. | Neuilly, Mélanie-Angela, 1977- editor. Title: Mothering from the field : the impact of motherhood on site-based research / Bahiyyah Miallah Muhammad, Mélanie-Angela Neuilly, editors.

Description: New Brunswick : Rutgers University Press, [2019] | Includes bibliographical references and index.

Identifiers: LCCN 2018043050 | ISBN 9781978800564 (pbk.) | ISBN 978197880057I (hbk.) Subjects: LCSH: Women college teachers. | Women social scientists. | Women scientists. | Research-Methodology. | Social sciences_Fieldwork. | Science_Fieldwork. | Working mothers. | Work and family.

Classification: LCC LB2332.3.M68 2019 | DDC 378.1/2082-dc23

$\mathrm{LC}$ record available at https://lccn.loc.gov/2018043050

A British Cataloging-in-Publication record for this book is available from the British Library.

This collection copyright $\left({ }^{\circ} 2019\right.$ by Rutgers, The State University of New Jersey Individual chapters copyright $\left({ }_{2} 2019\right.$ in the names of their authors All rights reserved

No part of this book may be reproduced or utilized in any form or by any means, electronic or mechanical, or by any information storage and retrieval system, without written permission from the publisher. Please contact Rutgers University Press, I06 Somerset Street, New Brunswick, NJ 0890 . The only exception to this prohibition is "fair use" as defined by U.S. copyright law.

(@) The paper used in this publication meets the requirements of the American National Standard for Information Sciences-Permanence of Paper for Printed Library Materials, ANSI Z39.48-1992.

www.rutgersuniversitypress.org

Manufactured in the United States of America 
To our families, near and far Jaelah, Jian, and Grace, may you grow up to change the world 
